\title{
PELATIHAN PENYUSUNAN PANDUAN SEKOLAH SEHAT DALAM RANGKA IKHTIAR PENCEGAHAN COVID 19 BAGI GURU PAUD
}

\author{
UNA ZAIDAH ${ }^{1, *}$, BAIQ ROHIYATUN ${ }^{2}$, LU'LUIN NAJWA ${ }^{3}$, ENENG GARNIKA ${ }^{4}$, \\ DEWI RAYANI ${ }^{5}$

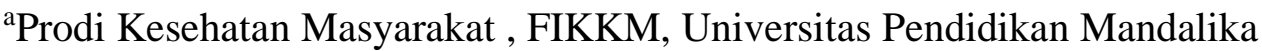 \\ Afiliasi penulis kedua dan Ketiga (Administrasi Pendidikan) \\ Afiliasi Penulis dan kelima (Bimbingan dan Konseling) \\ Email Korespondensi: bqrohiyatun@undikma.ac.id
}

\begin{abstract}
ABSTRAK
Pendidikan sehat di sekolah utamanya difokuskan pada strategi membuat sekolah yang memiliki lingkungan belajar yang normal atau tidak sakit, baik secara fisik dan mental. Sekolah sehat ditandai dengan situasi yang bersih, indah, tertib dan adanya nilai-nilai keluarga dalam rangka mencapai kesejahteraan internal dan eksternal dari semua warga sekolah. Sekolah yang sehat membuat setiap warga sekolah melakukan kegiatan yang bermanfaat, berguna dan efektif untuk sekolah dan luar sekolah. Upaya menjaga sekolah sehat saat covid-19 di PAUD PERMATA BANGSA Kodya Asri Mataram sudah diupayakan, namun belum memiliki panduan dalam upaya menyelenggarakan sekolah sehat sesuai standar. Keberadaan sekolah sehat merupakan hal terpenting sebagai salah satu upaya mengutamakan kesehatan atau kebiasaan hidup sehat di sekolah yang diterapkan di lingkungan sekolah pada saat situasi covid 19 dan selanjutnya. Hasil kegiatan Pengabdian Pada Masyarakat yaitu telah disusun draf Panduan Sekolah Sehat yang nantinya akan dikembangkan oleh guru dan dapat diimplementasikan dalam proses pembelajaran di PAUD Permata Bangsa.
\end{abstract}

Kata Kunci: standar, sekolah sehat

ABSTRACT

The healthy education in schools is mainly focused on strategies to create the schools that have a normal learning environment, both physically and mentally. The healthy schools is characterized by a clean, beautiful, orderly situation and existence of family values in order to achieve the internal and external well-being of all school members. The healthy school makes every school member carry out useful, effective activities for school and outside of school. The efforts to maintain healthy schools during Covid-19 at PAUD Permata Bangsa Kodya asri Mataram have been attempted, but not have guidelines in an effort to organize healthy schools according to standards. The existence of the healthy schools is the most important this as an effort to prioritize health or healthy living habits in schools that are applied in the school environment during the Covid-19 situation and beyond. The result of this activities is there is a healthy school guide draft that prepared which is will be developed by teachers and can be implemented in the learning process at PAUD Permata Bangsa.

Keywords: Healthy School Guide; Covid-19 Prevention

\section{PENDAHULUAN}

Kementrian Pendidikan dan Kebudayaan saat ini sedang mengembangkan Gerakan Sekolah Sehat, Aman, Ramah Anak dan Menyenangkan. Sekolah Aman, Ramah Anak, dan Menyenangkan sesungguhnya bukanlah hal yang baru dalam dunia Pendidikan karena beberapa sekolah sudah melaksanakan gerakan ini baik secara parsial maupun komprehesif dalam aktivitas kesehariannya.

Sekolah Sehat adalah keadaan badan dan jiwa yang baik. Artinya, sesuatu dikatakan sehat jika secara lahiriah, batiniah, dan sosial berjalan secara normal dan baik, sehingga memungkinkan sesuatu dapat produktif, baik secara sosial maupun ekonomis. Jika hal ini dikaitkan dengan lembaga pendidikan, maka sekolah sehat dapat dimaknai sebagai adalah lembaga pendidikan yang memiliki unsur-unsur yang baik (normal) secara lahiriah (jasmani) 
dan batiniah (rohani). Sekolah sehat pada prinsipnya terfokus pada usaha bagaimana membuat sekolah tersebut memiliki kondisi lingkungan belajar yang normal (tidak sakit) baik secara jasmani maupun rohani. Hal ini ditandai dengan situasi sekolah yang bersih, indah, tertib, dan menjunjung tinggi nilai-nilai kekeluargaan dalam kerangka mencapai kesejahteraan lahir dan batin setiap warga sekolah. Dengan begitu, sekolah sehat memungkinkan setiap warganya dapat melakukan aktivitas yang bermanfaat, berdaya guna dan berhasil guna untuk sekolah tersebut dan lingkungan di luar sekolah. Adapaun Standar Sekolah Sehat yaitu :

1. Memiliki lingkungan sekolah bersih, indah, tertib, rindang dan memiliki penghijauan yang memadai.

2. Memiliki tempat pembuangan dan pengelolaan sampah yang memadai dan representatif.

3. Memiliki air bersih yang memadai dan memenuhi syarat kesehatan.

4. Memiliki kantin dan petugas kantin yang bersih dan rapi, serta menyediakan menu bergizi seimbang.

5. Memiliki saluran pembuangan air tertutup dan tidak menimbulkan bau tak menyenangkan.

6. Memiliki ruang kelas yang memenuhi syarat kesehatan (ventilasi/AC dan pencahayaan cukup).

7. Memiliki ruang kelas yang representatif dengan ratio kepadatan jumlah siswa di dalam kelas adalah 1: $2 \mathrm{~m} 2$.

8. Memiliki sarana dan prasarana pembelajaran memenuhi standar kesehatan, kenyamanan dan keamanan.

9. Memiliki ruang dan peralatan UKS yang ideal. (tersedia tempat tidur; timbangan berat badan, alat ukur tinggi badan, snellen chart; kotak P3K berisi obat; lemari obat, buku rujukan, KMS, poster-poster, struktur organisasi, jadwal piket, tempat cuci tangan/wastafel, data angka kesakitan siswa; peralatan perawatan gigi, unit gigi; contohcontoh model organ tubuh, rangka torso dan lain-lain).

10. Memiliki toilet (WC) dengan ratio untuk siswi $1: 25$ dan siswa 1: 40.

11. Memiliki taman/kebun sekolah yang dimanfaatkan dan diberi tabel (untuk sarana belajar) dan pengolahan hasil kebun.

12. Memiliki kurikulum pembelajaran yang baik bagi tumbuh kembang siswa.

13. Memiliki kehidupan sekolah yang menjunjung tinggi nilai-nilai kekeluargaan.

14. Memiliki pola hidup bersih, higienis dan sehat

Dengan adanya Panduan Sekolah Sehat ini, maka kesehatan dalam jiwa, fisik maupun mental anak-anak sekolah bisa terdidik khususnya dalam bidang kebersihan lingkungan, sehingga terbiasa hidup dengan pola yang bersih diterapkan melalui sekolah dan dapat tularkan diluar lingkungan sekolah.

\section{METODE PELAKSANAAN}

Penentuan suatu metode dalam melaksanakan suatu kegiatan dapat membantu suksesnya rangkaian kegiatan yang dimaksud. Dampak positif dari penerapan metode dalam suatu kegiatan yaitu dapat terlaksananya rangkaian kegiatan yang telah dirancang secara maksimal. Langkah-langkah dalam pelaksanaan pengabdian dengan judul Pelatihan Penyusunan Panduan Sekolah Sehat Dalam Rangka Menyelenggarakan Sekolah sehat sesuai standar dan Ikhtiar Hidup sehat serta Pencegahan Covid 19 Bagi Guru PAUD antara lain:

1. Memberikan pelatihan kepada guru dalam penyusunan panduan sekolah sehat.

2. Melakukan sesi tanya jawab setiap akhir penyampaian materi pelatihan.

3. Evaluasi penggunaan buku panduan dan pelaksanaan sekolah sehat.

\section{HASIL DAN PEMBAHASAN}

Sesuai amanat UUD 1945 Pasal 28 B bahwa setiap anak berhak atas kelangsungan hidup, tumbuh, dan berkembang serta berhak atas perlinfungan dari kekerasan dan diskriminasi. UU 36/2009 pasal 79 "Kesehatan sekolah diselenggarakan untuk meningkatkan kemampuan hidup sehat peserta didik dalam lingkungan hidup sehat sehingga peserta didik dapat belajar, 
tumbuh, dan berkembang secara harmonis dan setinggi-tingginya menjadi sumber daya manusia yang berkualitas".

Kegiatan Pengabdian ini dilaksanakan selama 1 Bulan dengan 6 (enam) kali pertemuan, secara umum dapat dilaksanakan secara lancar. Peserta pelatihan seluruh komponen PAUD Permata Bangsa. Tempat pelatihan ruang sentra yang cukup luas sehingga tetap dapat mengikuti protokol kesehatan dengan selalu menjaga jarak.

Sebelum melakukan kegiatan pelatihan, pemateri dan seluruh TIM memperkenalkan diri terlebih dahulu kemudian mencoba menggali pengetahuan dasar tentang sekolah sehat. Pemateri mengajukan beberapa pertanyaan mengenai sekolah sehat, ciri-ciri sekolah sehat, pola hidup bersih dan sehat, perencanaan pelaksanaan sekolah sehat yang baik dan benar di sekolah. Setelah menggali pengetahuan dasar kemudian pemateri mulai memaparkan materi kebijakan dan dilanjutkan materi pola hidup bersih dan sehat. Selama kegiatan pelatihan berlangsung tampak peserta antusias dan memperhatikan isi materi yang disampaikan..

Pada pertemuan ke dua pemaparan tentang materi Penyusunan Panduan Sekolah Sehat. Pada pertemuan ke 3 dan pertemuan ke 4 guru dilatih untuk membuat panduan dengan indikator sesuai dengan standar yang sesuai, termasuk membuat instrument sekolah bersih dan sehat.Pada pertemuan ke 5 dan 6 dilakukan evaluasi atas pedoman penyusunan sekolah sehat di PAUD Permata Bangsa. Pada pertemuan ke 6 ditemukan, tim PAUD Permata Bangsa sudah menyusun draf panduan dan dari pihak lembaga sudah mencoba mengimplementasikan evaluasi sekolah bersih dan sehat dengan menggunakan instrument yang telah dibuat.

Selain itu pola hidup sehat juga sudah mulai diterapkan melalui atuaran yang dibuat, seluruh peserta didik dianjurkan untuk membawa bekal makanan sehat, dibiasakan minum air putih yang cukup, serta secara rutin melakukan aktivitas fisik diluar ruangan sebelum melaksanakan proses pembelajaran dimasing-masing sentra bermain.

Adapun kendala yang dijumpai selama proses kegiatan pelatihan adalah peserta tidak pernah lengkap, berhubung berhalangan hadir karena kondisi kesehatan dan ada juga yang tidak dapat hadir karena anaknya sakit. Walau ada kendala namun program kegiatan diharapkan dapat dilaksanakan secara berkelanjutan dengan adanya kerjasama dan pendampinya secara kontinyu dari para akademisi guna meningkatkan kompetensi pendidik dan tenaga kependidikan serta dapat meningkatkan kualitas layanan yang berdampak terhadap kepuasan para orang tua peserta didik dan seluruh peserta didik dapat bertumbuh dan mengembangkan potensinya secara sehat. .

\section{KESIMPULAN}

Pelatihan penyusunan panduan sekolah sehat di PAUD dapat meningkatkan pengetahuan guru-guru PAUD tentang standar pola hidup sehat di lingkungan sekolah. Pelatihan ini dilakukan dengan metode ceramah dan tanyajawab interaktif. Panduan sekolah sehat dapat dimanfaatkan sekolah dalam merencanakan, melaksanakan, dan mengevaluasi sekolah sehat. Penilaian awal dilakukan untuk mendapatkan data awal mengenai kondisi kesehatan sekolah, kegiatan pola hidup sehat yang diterapkan di sekolah, kemudian dilanjutkan dengankegiatan pembinaan oleh tim pengabdian kepada masyarakat Universitas Pendidikan Mandalika. Penilaian akhir dilakukan untuk mengevaluasi kondisi kesehatan sekolah, sikap peserta didik dan guru setelah dilaksanakannya pengabdian penyusunan panduan sekolah sehat. Hasil evaluasi dari instrumen yang digunakan diharapkan dapat dilanjutkan dengan terbitnya buku panduan sekolah sehat bagi Pendidikan Anak Usia Dini.

\section{DAFTAR PUSTAKA}

Asmawati, L. 2008. Kegiatan Pengembangan Anak Usia Dini. Jakarta:Universitas Terbuka. Handayani Purba, dkk.2020. Ilmu Kesehatan Anak. Yayasan Kita Menulis.

Latif, M. 2013. Orientasi Baru Pendidikan Anak Usia Dini. PT Fajar interpratama Mandiri. Guritnaningsi h, dkk. 2019. Sekolah Sehat Berkarakter Sekolah Dasar. Kementerian Pendidikan Dan Kebudayaan Direktorat Jenderal Pendidikan Dasar Dan Menengah. 
Deputi Tumbuh Kembang Anak.2015. Panduan Sekolah Ramah Anak. Kementrian Pemberdayaan Perempuan dan Perlindungan Anak Republik Indonesia. 